\title{
Tipologi Ekonomi Komoditas Perikanan dan Status Sektor Perikanan Pada Pembangunan Wilayah di Kabupaten Bandung Barat
}

\author{
Typology Economic of Fisheries Commodities And Fishery Sector Development Status \\ In The West Bandung Regency
}

\author{
Achmad Rizal $^{1 *}$, Iis Rostini ${ }^{1}$, Asep Agus Handaka ${ }^{1}$, dan Hana Siti Maharani ${ }^{2}$ \\ ${ }^{1}$ Staf Pengajar Fakultas Perikanan dan Ilmu Kelautan (FPIK) Universitas Padjadjaran \\ ${ }^{2}$ Alumni FPIK Universitas Padjadjaran \\ arizrzl@gmail.com
}

\begin{abstract}
Abstrak
Tujuan penelitian ini adalah untuk menentukan tipologi sektor perikanan di Kabupaten Bandung Barat; menganalisis laju pertumbuhan sektor perikanan dalam lima tahun terakhir (2009-2013) Kabupaten Bandung Barat; dan untuk menganalisis peran perikanan sektor pada pembangunan daerah Kabupaten Bandung Barat. Metode penelitian yang digunakan adalah metode survey dengan menggunakan beberapa teknik analisis, yaitu analisis Klassen Tipologi, analisis (LQ), analisis Localization Index (LI), analisis Spesialization Index (SI) dan Shift Share (SS). Hasil penelitian menunjukkan bahwa potensi terbaik dari komoditas di Kabupaten Bandung Barat adalah ikan patin / Pengasius hypophthalmus (jumlah rata-rata LQ komoditas 1,92). Poin keunggulan daerah dengan menggunakan LQ (rata-rata nilai 1,82), LI (di bawah 0,5), dan SI $(0,01$ nilai 0,07-0,09 / nilai di bawah 0,5). Titik LQ menunjukkan bahwa sektor perikanan di Kabupaten Bandung Barat adalah sektor basis, tetapi poin lain (LI dan SI) menunjukkan bahwa sektor perikanan bukanlah sektor penggerak pada struktur perekonomian wilayah. Berdasarkan tipologi Klassen dan teknik Shift-Share, sektor perikanan di Kabupaten Bandung Barat merupakan sektor dengan pertumbuhan yang lambat dan kurang kompetitif (pada tipologi klassen berada di kuadran 2).
\end{abstract}

Kata kunci: Perikanan, Pembangunan Daerah, Tipologi

\begin{abstract}
The aims of this research were to determine the typology of fishery sector in West Bandung regency, to analyzed the rate of growth of the fisheries sector in recent five years (2009-2013) of West Bandung regency, and to analyzed the role of the fisheries sector on regional development of West Bandung regency. Research method used is survey method by several technical analysis, they are analysis Klassen Typology, Localication Quetiont (LQ), Localization Index (LI), Specialization Index (SI) and Shift Share (SS). The results show that the best potential of commodity in West Bandung regency is catfish/Pengasius (the average number of 1,92). The points of regional advantages by using LQ (LQ average of point number as 1,82), LI (under 0,5$)$, and SI (0,01 0,07-0,09/points value under 0,5). The point of LQ indicates that the fishery sector in West Bandung Regency is a sector basis, but another points (LI and SI) indicate that the fishery sector is not the prime mover sector of regional economic sector. Based on Klassen typology and Shift Share technique, fishery sector in West Bandung regency is a sector with slow growth and less competitive (at quadrant 2 in klassen typology).
\end{abstract}

Keywords : Fishery, Regional Development, Typology. 


\section{Pendahuluan}

Tipologi pembangunan dalam suatu daerah khususnya di Kabupaten Bandung Barat, memliki tiga faktor, yaitu faktor alami, kondisi sosial budaya, dan keputusankeputusan kebijakan. Faktor alami meliputi kondisi agriklimat, sumberdaya alam, letak geografis, jarak pelabuhan dengan pusat aktivitas ekonomi, wilayah potensial untuk pembangunan ekonomi. Sementara faktor sosial budaya meliputi nilai, tradisi, mobilitas ekonomi, inovasi, dan kewirausahaan. Faktor keputusan kebijakan adalah sejumlah kebijakan yang mendukung secara langsung atau tidak langsung terjadinya tipologi pembangunan yang terjadi (United Nation, 2001).

Sektor basis yang merupakan sektor unggulan adalah sektor ekonomi di suatu wilayah yang keberadaannya telah berperan besar terhadap perkembangan perekonomian wilayah tersebut. Salah satunya dilihat dari indikator memiliki pertumbuhan yang tinggi serta penyerapan tenaga kerja yang besar. Sektor perikanan merupakan sektor yang sangat penting dan potensial dalam pertumbuhan ekonomi nasional dan daerah baik dilihat dari segi pendapatan maupun penyerapan tenaga kerja (Rizal, 2006; Rizal.et.al, 2008).

Kabupaten Bandung Barat merupakan salah satu produsen ikan di Jawa Barat. Kabupaten Bandung Barat secara geografis, demografis dan klimatologis sangat sesuai dalam pengembangan usaha perikanan, khususnya perikanan budidaya, dimulai dari pembenihan, pendederan, pembesaran sampai pengolahan ikan. Nilai Produksi perikanan dalam pembentukan PDRB Kabupaten Bandung Barat meningkat setiap tahunnya.

Potensi yang besar belum dapat menunjukkan sektor perikanan merupakan sektor basis khususnya di Kabupaten Bandung Barat yang dapat menjadi sektor unggulan. Selain hal tersebut, potensi yang besar belum dapat menentukan peran sektor perikanan besar serta berdampak terhadap pembangunan wilayah. Dari pemaparan tersebut, maka menjadi hal yang penting dilakukan analisis peran sektor perikanan terhadap wilayah kabupaten Bandung Barat.
Penelitian ini bertujuan menentukan menentukan tipologi sektor perikanan di Kabupaten Bandung Barat; menganalisis laju pertumbuhan sektor perikanan dalam lima tahun terakhir (2009-2013) Kabupaten Bandung Barat; dan untuk menganalisis peran perikanan sektor pada pembangunan daerah Kabupaten Bandung Barat. Harapan dari terlaksanannya penelitian ini adalah dapat bermanfaat bagi pengambil keputusan khususnya pemerintah daerah sebagai bahan pertimbangan dalam menyusun perencanaan dan strategi bagi pembangunan sektor perikanan serta bagi pihak lain, sebagai referensi untuk menambah wawasan, informasi serta pengetahuan.

\section{Metode Penelitian}

Penelitian dilakukan di Kabupaten Bandung Barat dari bulan Januari sampai dengan bulan Agustus 2015. Metode pengumpulan data dilakukan dengan metode survei. Teknik pengumpulan data yang dilakukan dalam penelitian ini adalah dengan cara studi literatur dan wawancara.

Analisis data yang digunakan dalam penelitian ini adalah deskriptif kuantitatif. Adapun analisis kuantitatif digunakan analisis dengan metode keunggulan komoditas, keunggulan wilayah, dan pertumbuhan ekonomi.

\section{Analisis tipologi klassen}

Analisis tipologi klassen, yaitu melihat koefisien rasio pertumbuhan dan kontribusi subsektor dalam Produk Domestik Regional Brutto (Syafrizal, 1997). Berdasarkan Analisis Tipologi Klasen (Kuncoro, Mudrajat dan Hairul Aswandi, 2002) terdapat 4 (empat) kategori sektoral yang di bagi atas 4 kuadran:

Kuadran pertama (KW 1), Adalah sektor yang maju dan tumbuh dengan pesat. Kuadran ini merupakan kuadran sektor dengan laju pertumbuhan PDRB (gi) yang lebih besar dibandingkan dengan pertumbuhan daerah yang menjadi acuan atau secara nasional (g) dan memiliki pertumbuhan PDRB perkapita (gki) yang lebih besar dibandingkan dengan pertumbuhan PDRB perkapita daerah yang menjadi acuan atau secara nasional (gki). 
Klasisfikasi ini biasa dilambangkan dengan gi $>$ g dan gki $>$ gk.

Kuadran kedua (KW II) adalah sektor maju tapi tertekan. Makna maju dan tertekan adalah sektor yang berada pada kuadran ini memiliki nilai pertumbuhan PDRB (gi) yang lebih rendah dibandingkan pertumbuhan PDRB daerah yang menjadi acuan atau secara nasional (g), tetapi memiliki pertumbuhan PDRB perkapita (gki) yang lebih besar dibandingkan pertumbuhan PDRB perkapita sektor yang menjadi acuan atau secara nasional (gk). Klasifikasi ini biasa dilambangkan dengan gi $<$ g dan gki $>$ gk.

Kuadran ke tiga (KW III) adalah sektor potensial atau masih dapat berkembang dengan pesat. Kuadran ini merupakan kuadran untuk daerah yang memiliki nilai pertumbuhan PDRB (gi) yang lebih tinggi dari pertumbuhan daerah yang menajdi acuan atau secara nasional (g), tetapi memiliki pertumbuhan PDRB perkapita daerah yang (gki) lebih kecil dibandingkan dengan pertumbuhan PDRB perkapita daerah yang menjadi acuan atau secara nasional (gk). Klasifikasi ini biasa dilambangkan dengan gi $>$ g dan gki $<$ gk.

Kuadran keempat (KW IV) ditempati oleh sektor yang memiliki nilai pertumbuhan PDRB (gi) yang lebih rendah dibandingkan dengan pertumbuhan PDRB sektor acuan atau secara nasional (g) dan sekaligus memiliki pertumbuhan PDRB perkapita (gki) yang lebih kecil dibandingkan pertumbuhan PDRB perkapita sektor acuan atau secara nasional (gk). Klasifikasi Sektor/daerah menurut pendekatan tipologi klassen dapat dilihat pada gambar matriks di bawah ini.

\begin{tabular}{c|c|}
\hline Kuadran I & Kuadran II \\
Daerah maju dan tumbuh dengan pesat & Daerah maju tapi tertekan \\
$\mathrm{g}_{\mathrm{i}}>\mathrm{g}, \mathrm{g} \mathrm{k}_{\mathrm{i}}>\mathrm{gk}$ & $\mathrm{g}_{\mathrm{i}}<\mathrm{g}, \mathrm{gk}>\mathrm{gk}$ \\
\hline Kuadran III & Kuadran IV \\
$\begin{array}{c}\text { Daerah yang masih dapat berkembang } \\
\text { dengan pesat } \\
\mathrm{g}_{\mathrm{i}}>\mathrm{g}, \mathrm{g} \mathrm{k}_{\mathrm{i}}<\mathrm{gk}\end{array}$ & Daerah relatif tertinggal \\
\hline
\end{tabular}

Gambar 1. Matrik Tipologi Sektor/Daerah

Figure 1. Typology of Matrix Sector/ Region

\section{Metode Analisis Keunggulan Wilayah}

\section{a. Analisis LQ}

Model Analisis Location Quetiont (LQ) adalah teknik penghitungan untuk mengetahui sektor basis dan non basis dengan membandingkan persentase sumbangan sektor perikanan (Rizal, 2013).

$$
L Q=\frac{X_{I J}}{X_{I}} / \frac{X_{. J}}{X_{-}}
$$

Keterangan :

LQ : nilai LQ sektor di Kabupaten Bandung Barat
$\mathrm{X}_{\mathrm{IJ}}$ : PDRB sektor perikanan di Kabupaten Bandung Barat

$X_{\text {I. }} \quad$ : PDRB seluruh sektor di Kabupaten Bandung Barat

$\mathrm{X}_{\mathrm{J}} \quad$ : PDRB sektor di Provinsi Jawa Barat

X.. : PDRB seluruh sektor di Provinsi Jawa Barat

Koefisien LQ $<1$ berarti bahwa sektor yang bersangkutan tidak memiliki keunggulan komparatif. Koefisien LQ $=1$ maka sektor tersebut memiliki keunggulan komparatif yang sama dengan rata-rata semua daerah. Koefisien LQ $>1$ memiliki arti bahwa sektor yang bersangkutn memiliki keunggulan komparatif yang lebih dari rata-rata atau dengan kata lain merupakan sektor basis (Rizal, 2013). 
Achmad Rizal : Tipologi Ekonomi Komoditas Perikanan dan Status Sektor Perikanan Pada Pembangunan Wilayah di Kabupaten Bandung Barat

\section{b. Analisis Localization Index (LI)}

Analisis Localization Index (LI) merupakan teknik analisis yang menunjukkan suatu aktivitas berkembang disemua wilayah (dispersion) atau relatif berkembang hanya diwilayah tertentu saja (localization/concentration).

$$
L I_{j}=1 / 2 \sum_{I=1}^{n}\left\{\left|\frac{X_{I J}}{X_{. J}}-\frac{X_{L}}{X_{-}}\right|\right\}
$$

Keterangan :

$\mathrm{LI}_{\mathrm{J}} \quad$ : nilai LI sektor perikanan total wilayah

$\mathrm{X}_{\mathrm{IJ}}$ : PDRB sektor perikanan di Kabupaten Bandung Barat

$\mathrm{X}_{\mathrm{I}} \quad$ : PDRB seluruh sektor di Kabupaten Bandung Barat

$\mathrm{X}_{J} \quad$ : PDRB sektor di Provinsi Jawa Barat X.. : PDRB seluruh sektor di Provinsi Jawa Barat

Jika hasil analisis memiliki nilai mendekati 0 maka artinya tingkat perkembangan kegiatan relatif disemua wilayah (terdispersi), sedangkan hasil analisis memiliki nilai mendekati 1 maka artinya aktivitas yang diamati berkembang secara memusat (terkonsentrasi).

\section{c. Analisis Specialization Index (SI)}

Analisis Specialization memiliki fungsi yang hampir sama dengan analisis LI yakni sebagai analaisis pelengkap dan memperkuat hasil analisis LQ. Analisis SI digunakan untuk mengkategorikan bahwa suatu wilayah memiliki aktivitas terdiversifikasi (diversification) atau memiliki aktivitas terspesialisasi (specialization). Adapun analisis SI dapat dirumuskan dalam persamaan sebagai berikut:

$$
S I_{I}=1 / 2 \sum_{J=1}^{P}\left\{\left|\frac{X_{I J}}{X_{I .}}-\frac{X_{. J}}{X_{-}}\right|\right\}
$$

Keterangan :

$\mathrm{SI}_{\mathrm{I} .} \quad$ : nilai SI untuk total sektor di Kabupaten Bandung Barat
$\mathrm{X}_{\mathrm{IJ}}$ : PDRB sektor perikanan di Kabupaten Bandung Barat

$\mathrm{X}_{\mathrm{I}} \quad$ : PDRB seluruh sektor di Kabupaten Bandung Barat

$\mathrm{X}_{\mathrm{J}} \quad$ : PDRB sektor di Provinsi Jawa Barat

X.. : PDRB seluruh sektor di Provinsi Jawa Barat

Jika hasil analisis memiliki nilai mendekati 0 maka artinya diwilayah tersebut memiliki berbagai aktivitas (diversifikasi), sedangkan hasil analisis memiliki nilai mendekati 1 maka artinya wilayah yang diamati memiliki aktivitas yang khas/spesial.

1. Metode Analisis Keunggulan Komoditas

$$
L Q=\frac{\frac{e_{i}}{e}}{/ \frac{E_{i}}{E}}
$$

Keterangan :

LQ : nilai LQ komoditas yang dianalisis

$\mathrm{e}_{\mathrm{i}}$ : Produksi komoditas ikan di Kabupaten Bandung Barat

e : Produksi seluruh komoditas di Kabupaten Bandung Barat

$\mathrm{E}_{\mathrm{i}}$ : Produksi komoditas ikan di Provinsi Jawa Barat

E : Produksi seluruh komoditas di Provinsi Jawa Barat

\section{Metode Analisis Pertumbuhan Ekonomi}

Analisis yang digunakan untuk pertumbuhan ekonomi yaitu analisis shift share. Analisis Shift share merupakan metode yang membandingkan perbedaan laju pertumbuhan berbagai sektor diwilayah dengan wilayah nasional. Rasio produksi digunakan untuk melihat perbandingan produksi sektor perikanan di suatu wilayah tertentu Rasio produksi terbagi atas ri, $\mathrm{Ri}$, dan $\mathrm{Ra}$.

a. ri

$$
r i=\frac{Y^{\prime} i j-Y i j}{Y i j}
$$

Keterangan : 
$Y^{\prime}$ ij : Produksi dari sektor perikanan pada wilayah kabupaten pada tahun akhir analisis

Yij : Produksi dari sektor perikanan pada wilayah kabupaten pada tahun dasar analisis

b. $\mathrm{Ri}$

$$
R i=\frac{Y^{\prime} i-Y i}{Y i}
$$

Keterangan :

Y'i : Produksi dari sektor perikanan provinsi pada tahun akhir analisis

$\mathrm{Yi}$ : Produksi dari sektor perikanan pada provinsi pada tahun dasar analisis

c. $\mathrm{Ra}$

$$
R a=\frac{Y^{r} \ldots-Y \ldots}{Y \ldots}
$$

Keterangan :

$\mathrm{Y}^{\prime}$... $\quad$ : Produksi provinsi pada tahun akhir analisis

Y... : Produksi provinsi pada tahun dasar analisis

Kemudian dilanjutkan dengan perhitungan Komponen pertumbuhan terdiri dari komponen pertumbuhan provinsi (KPP), komponen pertumbuhan proposional (PP) dan komponen pertumbuhan pangsa wilayah (PPW).

a. Komponen Pertumbuhan Provinsi (KPP)

$$
K P P i j=(R a) Y i j
$$

Keterangan :

KPPij : Komponen pertumbuhan provinsi sektor perikanan untuk wilayah

Yij : Produksi dari sektor perikanan untuk wilayah pada tahun dasar analisis.

$\mathrm{Ra} \quad$ : Rasio produksi provinsi

b. Komponen Pertumbuhan Proporsional (PP)

$P P i j=(R i-R a) Y i j$

Keterangan :

\begin{tabular}{rllr} 
Ppij & Komponen & \multicolumn{2}{c}{ pertumbuhan } \\
& $\begin{array}{l}\text { proporsional sektor } \\
\text { wilayah }\end{array}$ \\
Yij $\quad:$ Produksi/kesempatan kerja dari
\end{tabular} sektor perikanan pada wilayah pada tahun dasar analisis

Ri : Rasio produksi (propinsi) dari sektor perikanan

$\mathrm{Ra} \quad$ : Rasio produksi (propinsi)

Apabila PPij < 0, Menunjukkan bahwa sektor perikanan pada wilayah $\mathrm{j}$ pertumbuhannya lambat. PPij > 0, Menunjukkan bahwa sektor perikanan pada wilayah pertumbuhannya cepat.

c. Komponen Pertumbuhan Pangsa wilayah (PPW)

$$
P P W i j=(r i-R i) Y i j
$$

Keterangan :

PPWij : Komponen pertumbuhan pangsa wilayah sektor perikanan pada wilayah pada tahun dasar analisis

Yij : Produksi/kesempatan kerja dari sektor perikanan pada wilayah pada tahun dasar analisis

Ri : Rasio produksi/kesempatan kerja sektor perikanan pada wilayah

Ri : Rasio produksi/kesempatan kerja (propinsi) dari sektor perikanan

Apabila PPWij $>0$, berarti sektor/wilayah $\mathrm{j}$ mempunyai daya saing yang baik dibandingkan dengan sektor/wilayah lainnya untuk sektor i. PPWij < 0 , berarti sektor/wilayah $\mathrm{j}$ tidak mempunyai daya saing yang baik dibandingkan dengan sektor/wilayah lainnya.

Ditentukan profil pertumbuhan berdasarkan nilai persen perubahan komponen pertumbuhan proprosional (PNij) dan pertumbuhan pangsa wilayah (PWij) dan dihitung pergeseran bersihnya.

$$
P B i j=P P i j+P P W i j
$$

Apabila $\mathrm{PBij}>0$, maka pertumbuhan sektor perikanan pada wilayah termasuk ke dalam kelompok progresif (maju). $\mathrm{PBij}<0$, maka pertumbuhan sektor perikanan pada wilayah termasuk lamban. 


\section{Hasil dan Pembahasan}

Kabupaten Bandung Barat (KBB) memiliki dua waduk yaitu Waduk Saguling dan Waduk Cirata. Waduk Saguling berada di dalam administrasi beberapa Kecamatan diantaranya Kecamatan Saguling, Kecamatan Cipongkor, Kecamatan Cihampelas, Kecamatan Batujajar dan Kecamatan Cililin, sedangkan waduk lain yaitu Waduk Cirata berada di Kecamatan Cipeundeuy. Waduk dan situ yang terdapat di KBB merupakan sebagai salah satu pendukung sektor perikanan.

\section{Analisis Tipologi Klassen}

Sektor perikanan berdasarkan analisis Tipologi Klassen termasuk dalam kategori tipologi kuadran II atau sebagai sektor maju tapi tertekan secara kewilayahan di Kabupaten Bandung Barat. Sektor yang berada pada kuadran ini memiliki nilai pertumbuhan PDRB (gi) yang lebih rendah dibandingkan pertumbuhan PDRB daerah yang menjadi acuan atau secara nasional $(\mathrm{g})$, tetapi memiliki pertumbuhan PDRB perkapita (gki) yang lebih besar dibandingkan pertumbuhan PDRB perkapita sektor yang menjadi acuan atau secara nasional (gk). Klasifikasi ini biasa dilambangkan dengan $\mathrm{gi}<\mathrm{g}$ dan $\mathrm{gki}>\mathrm{gk}$.

Di kuadran II bersama Sektor Perikanan masuk juga Sektor Tanaman perkebunan; Sektor Peternakan dan hasil-hasilnya; Sektor Listrik, Gas dan Air Bersih; Sektor Bangunan; Sektor Pengangkutan dan Komunikasi; Sektor Keuangan, Persewaan dan Jasa Perusahaan, dan Sektor Jasa-Jasa. Secara rinci dapat dilihat pada Matrik di bawah ini.

Tabel 1. Matrik Tipologi Sektor Kabupaten Bandung Barat

Table 1. Matix Typologi West Bandung Regency

\begin{tabular}{|c|c|}
\hline $\begin{array}{l}\text { Kuadran I } \\
\text { Sektor maju dan tumbuh dengan pesat } \\
(\mathrm{gki}>\mathrm{gk}, \mathrm{gi}>\mathrm{g})\end{array}$ & $\begin{array}{l}\text { Kuadran II } \\
\text { Sektor maju tapi tertekan } \\
(\mathrm{gki}<\mathrm{gk}, \mathrm{gi}>\mathrm{g})\end{array}$ \\
\hline $\begin{array}{l}\text { Sektor: } \\
\text { Tanaman bahan makanan, Perdagangan, } \\
\text { Hotel dan Restoran. }\end{array}$ & $\begin{array}{l}\overline{\text { Sektor: }} \\
\text { Tanaman perkebunan; Peternakan dan hasil-hasilnya; } \\
\text { Perikanan; Listrik, Gas dan Air Bersih; Bangunan; } \\
\text { Pengangkutan dan Komunikasi; Keuangan, Persewaan } \\
\text { dan Jasa Perusahaan, Jasa-Jasa. }\end{array}$ \\
\hline $\begin{array}{l}\text { Kuadran III } \\
\text { Sektor potensial atau masih dapat berkembang } \\
\text { dengan pesat } \\
(\mathrm{gki}>\mathrm{gk} \text {, gi }<\mathrm{g})\end{array}$ & $\begin{array}{l}\text { Kuadran IV } \\
\text { Sektor relatif tertinggal } \\
(\text { gki }<\text { gk, gi }<\text { g) }\end{array}$ \\
\hline $\begin{array}{l}\text { Sektor: } \\
\text { Pertanian; Industri Pengolahan. }\end{array}$ & $\begin{array}{l}\text { Sektor: } \\
\text { Kehutanan, Pertambangan dan Penggalian }\end{array}$ \\
\hline
\end{tabular}

\section{Analisis Pertumbuhan Sektor}

Komponen Pertumbuhan Proporsional atau Komponen Share adalah komponen pertumbuhan ekonomi yang menjelaskan perbedaan kenaikan PDRB tingkat provinsi dengan PDRB tingkat Kabupaten/Kota (Ghufron 2008). Hal tersebut menunjukkan bahwa kebijakan daerah berpengaruh terhadap kontribusi sektor perikanan. Gambar 2 menunjukkan trend perkembangan nilai Komponen Pertumhunan Proporsional (KKP) dari tahun ke tahun. Nilai KPP cenderung meningkat setiap tahunnya. 


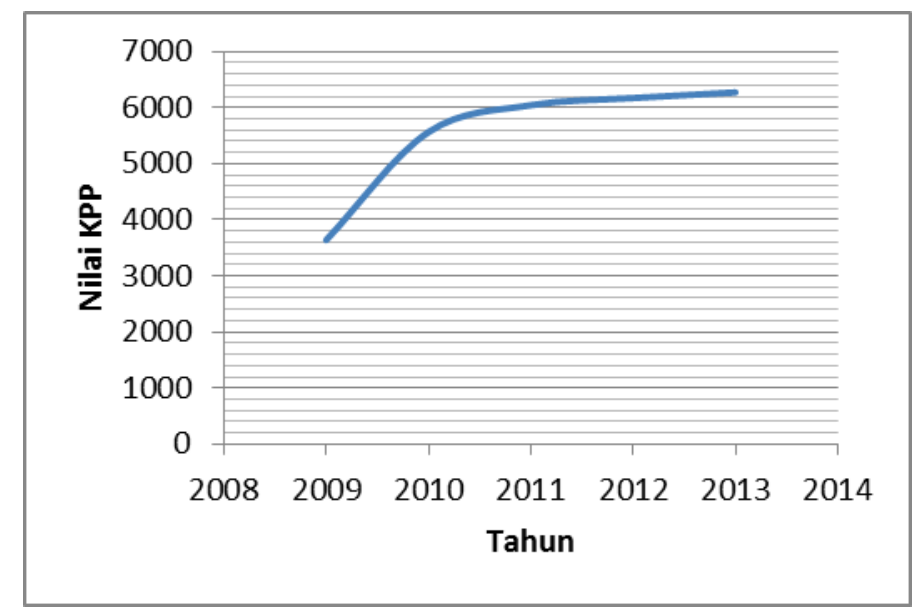

Gambar 2. Trend Nilai Komponen Share

Figure 2. Trend of Value Share Component

Pertumbuhan Proporsional (PP) menunjukkan kontribusi sektor perikanan terhadap provinsi. Tahun 2008/2009 dan tahun 2012/2013 sektor perikanan Kabupaten Bandung Barat memiliki pertumbuhan positif dengan $\mathrm{PP}>0$, sehingga disimpulkan pada tahun tersebut sektor perikanan di KBB memiliki laju pertumbuhan yang lebih cepat dibandingkan sektor perikanan di provinsi Jawa Barat.
Tahun 2009/2010, 2010/2011, dan 2011/2012 memiliki nilai PP negatif menunjukan bahwa pada tahun tersebut sektor perikanan di KBB memiliki laju pertumbuhan yang lebih lambat dibandingkan sektor perikanan di provinsi Jawa Barat. Gambar 3 menunjukkan perkembangan komponen mix dari tahun ke tahun.

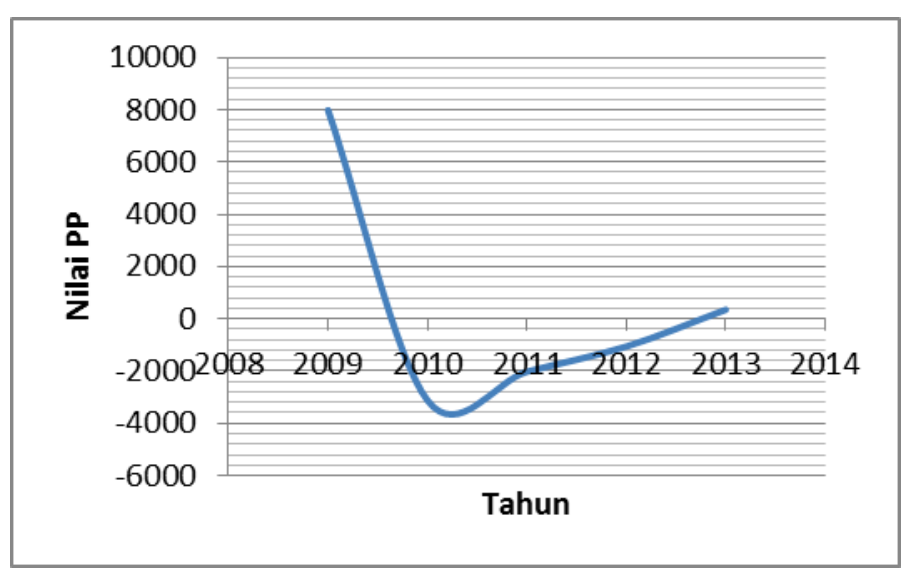

Gambar 3. Trend Nilai Komponen Mix

Figure 3. Trend of Value Mix Component

Gambar 4. menunjukkan trend perkembangan daya saing sektor perikanan Kabupaten Bandung Barat dengan wilayah lain. Komponen competitive yang ditunjukkan pada Gambar 4 memiliki rata-rata $-1.428,38$ merupakan nilai yang menunjukkan bahwa secara umum dalam perkembangan lima tahun terakhir yakni 2008-2013 menunjukkan bahwa sektor perikanan Kabupaten Bandung Barat tidak memiliki keunggulan dibandingkan kabupaten dan kota lain di Provinsi Jawa Barat. Sektor perikanan Kabupaten Bandung Barat belum memiliki daya saing dengan wilayah lain di Jawa Barat. Kabupaten Bandung Barat tidak memiliki subsektor perikanan laut. Wilayah yang 
Achmad Rizal : Tipologi Ekonomi Komoditas Perikanan dan Status Sektor Perikanan Pada Pembangunan Wilayah di Kabupaten Bandung Barat

memiliki sektor perikanan laut umumnya lebih unggul disebabkan produksi yang besar dan harga jual yang lebih tinggi dibandingkan dengan subsektor perikanan tawar.

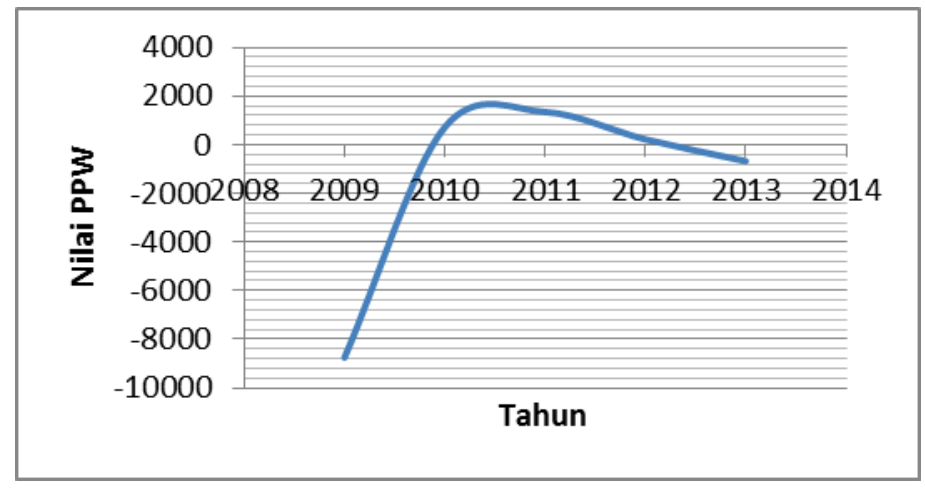

Gambar 4. Trend Nilai Komponen Competitive

Figure 4. Trend of Value Competitive Component

Berdasarkan perhitungan, sektor perikanan Kabupaten Bandung Barat rata-rata setiap tahunnya dari tahun 2008-2013 memiliki nilai pergeseran bersih dengan rata-rata $-1001,46$ menunjukkan bahwa sektor tersebut memiliki nilai $<0$. Nilai $<0$ menunjukkan sektor perikanan merupakan sektor yang memiliki pertumbuhan yang lambat. Hal tersebut tidak berarti negatif sebab sektor perikanan didominasi cabang usaha KJA. Berdasarkan hasil wawancara perkembangan KJA cenderung meningkat namun hasil produksi tidak sebanding dengan jumlah KJA. Hasil produksi dipengaruhi dari beberapa faktor, baik internal dan eksternal faktor dalam KJA tersebut. Faktor luar tersebut diantaranya faktor luar mencakup keadaan alam dan penyakit yang menyerang ikan, sedangkan faktor dalam mencakup cara budidaya dan penanganan oleh pembudidaya. Profil pertumbuhan menunjukkan bahwa sektor perikanan merupakan sektor basis yang memiliki pertumbuhan yang lambat (Gambar $5)$.

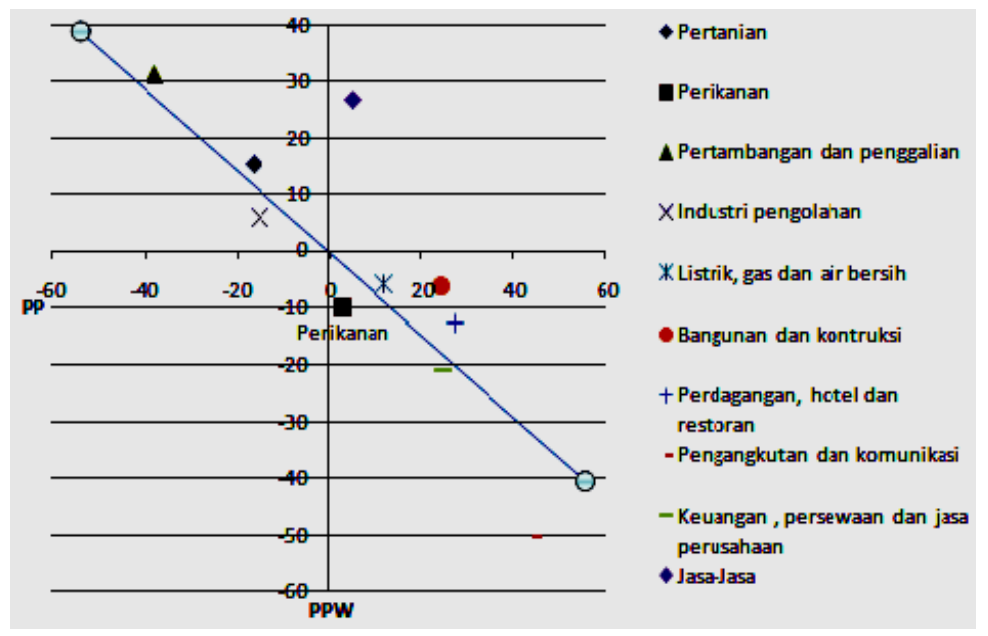

Gambar 5. Profil Pertumbuhan Sektor Perikanan Kabupaten Bandung Barat

Figure 5. The growth profile in the Fisheries Sector West Bandung Regency

Profil pertumbuhan sektor ditentukan berdasarkan persentase nilai PP dan PPW yang dapat dilihat pada Gambar 5 yang menunjukkan kuadran sektor perikanan berada pada kuadran II di bawah garis. Hal ini menunjukkan sektor perikanan merupakan 
sektor yang memiliki pertumbuhan yang lambat dengan daya saing yang rendah. Sektor perikanan di Kabupaten Bandung Barat didominasi oleh cabang usaha KJA yang produksinya cenderung menurun dan daya saing yang rendah dibandingkan daerah lain.

\section{Analisis Komoditas Unggulan}

Berdasarkan hasil produksi ikan di Kabupaten Bandung Barat dan di Jawa Barat, maka didapat hasil perhitungan LQ komoditas budidaya pada Tabel

Tabel 2. Hasil Perhitungan LQ Komoditas Budidaya Tahun 2009-2013

Table 2. Result of Comodity LQ Calculation 2009-2013 Period

\begin{tabular}{lllllcll}
\hline & \multirow{2}{*}{ No. } & Komoditas & \multicolumn{6}{c}{ Nilai LQ } \\
\cline { 3 - 8 } & 2009 & 2010 & 2011 & 2012 & 2013 & $\begin{array}{c}\text { Rata- } \\
\text { Rata }\end{array}$ \\
\hline 1. & Mas & 1,00 & 1,11 & 1,43 & 1,47 & 1,66 & 1,33 \\
2. & Nila & 1,26 & 1,38 & 1,04 & 1,22 & 1,33 & 1,24 \\
3. & Patin & 2,88 & 1,76 & 0,82 & 2,17 & 1,98 & 1,92 \\
4. & Lele & 0,06 & 0,15 & 0,20 & 0,12 & 0,07 & 0,11 \\
5. & Gurame & 0,24 & 0,65 & 0,96 & 0,30 & 0,51 & 0,53 \\
\hline
\end{tabular}

Ikan Patin merupakan jenis komoditas unggulan di Kabupaten Bandung Barat (KBB). Tiga jenis ikan yaitu ikan Patin, Ikan Mas, dan ikan Nila adalah jenis ikan yang paling banyak dibudidayakan pada cabang usaha keramba jaring apung. Telah diketahui sebelumnya bahwa sentra perikanan khususnya budidaya ikan konsumsi yang paling banyak dibudidayakan ialah di Kecamatan Cililin, Cihampelas dan Cipeundeuy. Ketiga Kecamatan tersebut merupakan sentra perikanan dengan cabang usaha budidaya pada KJA, sehingga jenis ikan yang paling banyak dibudidayakan merupakan jenis ikan yang dibudidayakan di KJA diantaranya ikan Mas, ikan Nila, dan ikan Patin. Ikan Nila dan ikan Mas dipilih karena jenis ikan tersebut tinggi permintaannya, mudah dibudidayakan dan waktu budidaya yang tergolong cepat panen dibandingkan ikan lainnya. Ikan Patin paling banyak dipilih pembudidaya disebabkan ikan tersebut tergolong ikan catfish yang tahan terhadap perubahan cuaca yang terjadi di waduk. Kelebihan lain dari ikan patin adalah harga jual yang lebih tinggi sehingga dapat meningkatkan nilai produksi perikanan.

\section{Analisis Keunggulan Wilayah}

Keunggulan wilayah sektor perikanan mesti dilihat dari beberapa indikator seperti Specialization Index (SI) dan Localization Index (LI) yang menjadi pembanding indeks LQ, karena seringkali indeks LQ tidak dapat menunjukkan sejauhmana keunggulan sektoral di dalam pertumbuhan wilayah, pada Tabel 2 ditampilkan hasil perhitungan LQ, SI dan LI.

Tabel 3. Rata-rata Hasil Perhitungan Analisis keunggulan wilayah

Table 3. Average Calculation of Regional Exellence Analysis

\begin{tabular}{lll}
\hline Nilai LQ & Nilai SI & Nilai LI \\
\hline 1,82 & 0,08 & 0,01 \\
\hline
\end{tabular}

Berdasarkan Tabel 2, maka sektor perikanan di Kabupaten Bandung Barat merupakan sektor basis (nilai LQ> 1) namun tidak menjadi fokus dan prioritas (nilai SI dan
$\mathrm{LI}<0,5)$ dibandingkan dengan sektor lain di Kabupaten Bandung Barat dan secara komparatif jika dibandingkan sektor perikanan di Kabupaten lain di Jawa Barat. 


\section{Kesimpulan dan Saran}

Berdasarkan penelitian yang dilakukan mengenai Tipologi ekonomi komoditas perikanan dan statu sektor perikanan terhadap pembangunan di wilayah Kabupaten Bandung Barat, maka dapat disimpulkan sebagai berikut :

1. Sektor Perikanan secara komparatif wilayah masuk dalam kategori sektor maju tapi tertekan (pertumbuhan lambat dan kurang kompetitif). Pada Tipologi Klassen Sektor Perikanan berada pada kuadran 2.

2. Pertumbuhan sektor perikanan dari tahun ke tahun sejak tahun 2008 sampai 2013 menunjukkan adanya peningkatan namun pertumbuhan tersebut tergolong lambat serta belum memiliki keunggulan kompetitif dibandingkan dengan daerah lain. Profil pertumbuhan menunjukkan bahwa sektor perikanan Kabupaten Bandung Barat merupakan sektor basis dengan daya saing yang rendah. Peranan sektor perikanan merupakan sektor basis (nilai LQ 1,82) namun bukan menjadi fokus dan tidak khusus dikembangkan di Kabupaten Bandung Barat.

3. Komoditas unggulan yang dapat dikembangkan di Kabupaten Bandung Barat menurut analisis LQ tahun 20082013 adalah ikan Patin (rata-rata nilai 1,92), kemudian diikuti oleh ikan lain diantaranya ikan mas (rata-rata nilai 1,33 ) dan ikan nila $(1,24)$.

Beberapa saran yang dapat diberikan dalam mendukung pembangunan Kabupaten Bandung Barat diantaranya:

1. Diperlukan adanya penelitian lanjutan keterkaitan daerah dalam analisis peran sektor perikanan dengan metode analisis lain yang belum dilakukan dalam penelitian ini.

2. Berdasarkan hasil analisis komoditas unggulan, perlu adanya penelitian komoditas ikan yang di budidayakan di Keramba Jaring Apung, dengan mempertimbangkan baik berdasarkan ekonomi maupun ekologi sehingga dapat dijadikan komoditas unggulan secara berkelanjutan.

3. Diperlukan peraturan yang khusus untuk budidaya dan penangkapan ikan di Waduk dan Situ dalam mendukung pengembangan sektor perikanan yang maksimal dan berkelanjutan.

\section{Daftar Pustaka}

[UN] United Nation. 2001. Economics and Social Commision for Asia and The Pacific. Reducing Disparitas: Balance Development of Urban and Rural Areas and Region Within the Countries of Asia and The Pacific. New York. Page 8.

Badan Pusat Statistik Jawa Barat. 2013. Kabupaten Bandung Barat Dalam Angka 2013. Bandung Barat.

Balai Besar Penelitian Sosial Ekonomi Kelautan dan Perikanan. 2012. Pengembangan Minapolitan Berbasis Perairan Umum Daratan. Badan Penelitian dan Pengembangan Kelautan dan Perikanan. Jakarta.

Ghufron, Muhammad. 2008. Analisis Pembangunan Wilayah Berbasis SektorUnggulan Kabupaten Lamongan Provinsi Jawa Timur. Skripsi. Institut Pertanian Bogor. Bogor.

Kabupaten Bandung Barat. Tanpa tahun. Sejarah KBB. www.bandungbarat.kab.go.id diakses pada tanggal 9 April 2016 pukul 10.39.

Kuncoro, Mudrajat dan Hairul Aswandi, 2002. Evaluasi Penetapan Kawasan Andalan : Studi Empiris di Kalimantan Selatan 1993-1999. Jurnal Ekonomi dan Bisnis Indonesia, Vol. 17, No. 1, 2002. Jakarta.

Martono, Primasto Ardi. 2008. Keterkaitan Antar Sektor Ekonomi dan Antar Daerah di Wilayah Kedungsepur. Tesis. Universitas Diponegoro. Semarang.

Muflikhati, Istiqialiyah; Nami Farmayanti dan Gatot Yulianto. 1996. Peranan Subsektor Perikanan dalam Perekonomian Wilayah Jawa Barat. Buletin Ekonomi Perikanan Vol. 2 No. 3.

Myrdal, Gunnar. 1957. Bangsa-Bangsa Kaya dan Miskin. Yayasan Obor dan PT Gramedia. Jakarta.

Nazir, M. 2005. Metode Penelitian. Ghalia Indonesia. Jakarta.

Nugroho, Iwan dan Rokhmin Dahuri. 2012. Pembangunan Wilayah (Perspektif Ekonomi, Sosial dan Lingkungan). LP3ES. Jakarta. 
Partawidagdo, Widjajono. 2004. Mengenal Pembangunan dan Analisis Kebijakan.

Program Pascasarjana Studi

Pembangunan Institut Teknologi

Bandung. Bandung.

Rizal, Achmad. 2006. Dampak Investasi Subsektor Perikanan terhadap Perekonomian Wilayah Kabupaten Cirebon. Jurnal Akuatika. Vol. IV no. 2.

Rizal, Achmad. 2013. Disparitas Pembangunan Wilayah Pesisir (Studi Kasus Kabupaten Tasikmalaya). Jurnal Akuatika. Vol. IV no. 2.

Rizal, Achmad; Asep Agus Handaka Suryana dan Iis Rostini. 2008. Peranan Subsektor Perikanan terhadap Perekonomian Wilayah Kabupaten Tasikmalaya. LPPM Universitas Padjadjaran. Bandung.

Suryana, Asep Agus Handaka. 2013. Dinamika Total Factor Productivity Perikanan Budidaya Air Tawar dan Dampaknya Terhadap Perekonomian Jawa Barat. Disertasi. Institut Pertanian Bogor. Bogor.

Syafrizal, 1997. Pertumbuhan Ekonomi dan Ketimpangan Regional Wilayah Indonesia Bagian Barat. Jurnal ekonomi dan pembangunan PRISMA edisi 3 Maret 1997. Jakarta.

Syahza, Almasdi. 2012. Ekonomi Pembangunan (Teori dan Kajian Empirik Pembangunan Pedesaan). Universitas Riau Press. Pekanbaru.

Wijaya, Bayu dan Hastarini Dwi Atmanti. 2006. Analisis Pengembangan Wilayah dan Sektor Potensial Guna Mendorong Pembangunan di Salatiga. Dinamika Pembangunan. Vol 3 No 2. 